\title{
Alfred Alexandre, Bord de canal
}

\section{Paola Ghinelli}

\section{(2) OpenEdition}

\section{Journals}

\section{Édition électronique}

URL : http://journals.openedition.org/studifrancesi/33867

DOI : 10.4000/studifrancesi.33867

ISSN : 2427-5856

\section{Éditeur}

Rosenberg \& Sellier

\section{Édition imprimée}

Date de publication : 1 décembre 2005

Pagination : 689

ISSN : 0039-2944

\section{Référence électronique}

Paola Ghinelli, «Alfred Alexandre, Bord de canal », Studi Francesi [En ligne], 147 (XLX | III) | 2005, mis en ligne le 30 novembre 2015, consulté le 18 avril 2021. URL : http://journals.openedition.org/ studifrancesi/33867 ; DOI : https://doi.org/10.4000/studifrancesi.33867

\section{Ce document a été généré automatiquement le 18 avril 2021.}

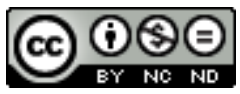

Studi Francesi è distribuita con Licenza Creative Commons Attribuzione - Non commerciale - Non opere derivate 4.0 Internazionale. 


\section{Alfred Alexandre, Bord de canal}

Paola Ghinelli 


\section{RÉFÉRENCE}

ALFRED ALEXANDRE, Bord de canal, Paris, Dapper, 2004 («Littérature»), pp.188.

1 Dans une banlieue indifférente et toxicomane, dans un décor minimaliste pétri de violence et de crasse, trois personnages tournent en rond tout en traînant le lecteur dans une spirale descendante, où l'horreur finit par laisser la place à une hébétude désemparée. Bord de canal exprime ainsi un abrutissement qui ne caractérise pas que les marginaux échoués «de l'autre côté de la vie». En effet, le quartier de Fort-de-France auquel le titre fait allusion ne lâche jamais ceux qu'il attire dans la déveine de ses entrailles, quel que soit leur statut social. Petit-Mari, un des personnages du roman, perdra un équilibre difficilement atteint pour descendre, à la lettre, aux enfers, car c'est dans le sous-sol de la ville qu'il se retrouvera, parmi les marchands de crack.

2 Ce roman a été remarqué par son refus d'un langage "créolisé» sur le modèle de Confiant ou de Chamoiseau, et il est certainement bon signe qu'un écrivain si jeune (il est né en 1970) puisse témoigner d'un style personnel et réfléchi dans son premier roman. Pourtant, la langue sèche et tranchante que nous propose Alfred Alexandre n'est peut-être pas la plus grande marque d'originalité de son œuvre, d'autant plus qu'on peut y repérer quelques concessions au français. Ce roman évoque de manière efficace la misère morale propre à un milieu dégradé.

Alexandre parvient à nous offrir une œuvre qui n'est ni documentaire, ni stéréotypée. Bien qu'une zone suburbaine réellement existante ait inspiré le décor dépouillé de ce roman, ses personnages incisifs et mystérieux (on ne connaît ni leur pensées ni leurs sentiments) représentent la solitude humaine. La banlieue dont la violence gratuite accable le lecteur est à interpréter au sens large, comme le bord qui hante chacun de nous. Bord de canal se rattache ainsi à une famille littéraire étrangère aux appartenances territoriales dont le point de repère est le non-lieu urbain et global. 